\title{
Photosynthetic Photon Flux Density, Carbon Dioxide Concentration and Temperature Influence Photosynthesis in Crotalaria Species
}

\author{
V.C. Baligar ${ }^{1, *}$, J.A. Bunce ${ }^{1}$, M.K. Elson ${ }^{1}$ and N.K. Fageria ${ }^{2}$ \\ ${ }^{1}$ USDA-ARS-Beltsville Agricultural Research Center, MD, 20705-2350, USA; ${ }^{2}$ EMBRAPA-National Rice and Bean \\ Research Center, Santo Antônio de Goiás, GO. 75375-000, Brazil
}

\begin{abstract}
Crotalarias are tropical legumes grown as cover crops or as green manure to improve soil fertility. As an understory plant in plantation systems, these cover crops receive low levels of irradiance and are subjected to elevated levels of $\mathrm{CO}_{2}$ and temperatures. A greenhouse experiment was conducted to evaluate the independent short-term effects of photosynthetic photon flux density (PPFD), external carbon dioxide concentration $\left(\mathrm{C}_{\mathrm{a}}\right)$ and temperature $(\mathrm{T})$ on net photosynthesis $\left(P_{\mathrm{N}}\right)$, internal $\mathrm{CO}_{2}\left(\mathrm{C}_{\mathrm{i}}\right)$, stomatal conductance $\left(\mathrm{g}_{\mathrm{s}}\right)$ and transpiration $(\mathrm{E})$ in four Crotalaria species (C. breviflora, C. mucronata, C. ochroleuca, C. spectabilis). These crotalarias responded differently to changing PPFD, $\mathrm{C}_{\mathrm{a}}$ and T. In all the Crotalaria species, increasing PPFD from 50 to $1500 \mu \mathrm{mol} \mathrm{m}^{-2} \mathrm{~s}^{-1}$ increased $P_{\mathrm{N}}$ by 21 fold, increased $\mathrm{g}_{\mathrm{s}}$ by 2.3 fold $(136 \%)$, decreased $\mathrm{C}_{\mathrm{i}}$ by 3.9 times, and increased $\mathrm{E}$ by 2.1 times. Increasing the external $\mathrm{C}_{\mathrm{a}}$ from 100 to $1000 \mathrm{~cm}^{3} \mathrm{~m}^{-3}$ increased $P_{\mathrm{N}}$ by 4.7 fold, decreased $\mathrm{g}_{\mathrm{s}}$ by 1.3 times, increased $\mathrm{C}_{\mathrm{i}}$ by 28 fold, and decreased $\mathrm{E}$ by 1.2 times. Increasing the $\mathrm{T}$ from 25 to $35{ }^{\circ} \mathrm{C}$ increased $P_{\mathrm{N}}$ of Crotalaria species by $11 \%$, decreased $\mathrm{g}_{\mathrm{s}}$ by $33 \%$, decreased $\mathrm{C}_{\mathrm{i}}$ by $64 \%$, and increased $\mathrm{E}$ by $56 \%$. Shade management is critical to maintaining the productivity of these tropical legumes.
\end{abstract}

Keywords: Leaf internal $\mathrm{CO}_{2}$ concentration, net photosynthesis, stomatal conductance, Crotalaria spp, transpiration rate.

\section{INTRODUCTION}

Perennial legumes are grown as green manure crops or as non-understory or understory cover crops in tropical regions in row crops or in plantation systems [1]. Legume cover crops improve soil fertility by fixing atmospheric $\mathrm{N}_{2}$, increasing soil organic matter content and soil aggregation, enhancing water holding capacity and improving biological activity $[1,2]$. They also reduce soil erosion, leaching and run-off losses of nutrients, and decrease weeds, diseases and pest infestations [1-3]. Various crotalaria species are grown in tropical regions as green manure crops, in fast growing row field crops or as understory cover crops in perennial plantation systems $[4,5]$. Crotalarias are fast-growing green manure or cover crops that can yield 5 to $10 \mathrm{t} / \mathrm{ha} / \mathrm{yr}$ of dry matter, fix $60-200 \mathrm{~kg} / \mathrm{ha} / \mathrm{yr}$ of nitrogen and improve soil quality components $[1,4,6]$. However, they have limited use as forage crops because they produce animal toxicity (pyrrolizidine alkaloids) [7].

Cover crops grown as understory plants in plantation systems receive very limited irradiance $[8,9]$. In addition to the global increase in $\mathrm{C}_{\mathrm{a}}[10]$, increased litter decomposition in plantation systems contributes additional $\mathrm{CO}_{2}$ at the canopy level. However information is lacking how these climatic variables affect the growth and physiological traits of crotalarias. Survivability and persistence of understory cover crops depends largely on the rate of $P_{\mathrm{N}}$, and this is affected by the amount and quality of light that reaches the

*Address correspondence to this author at USDA-ARS, 10300 Baltimore Ave, Building 001, Room 225, Beltsville, MD 20705-2350, USA; Tel: 301-504-6492; Fax: 301-504-1998;

E-mail: VC.Baligar@ars.usda.gov cover crop canopies $[9,11]$. In tropical regions incoming photosynthetic active radiation (PAR) is around $1800 \mu \mathrm{mol}$ $\mathrm{m}^{-2} \mathrm{~s}^{-1}$ [12], but understory plants in rainforests receive only 4 to $10 \%$ of this radiation $[8,13]$. Shading reduces yields of most tropical legumes $[9,11,14,15]$. Legume cover crops having greater tolerance to low light (high shade) intensity offer considerable promise by increasing their growth and persistence as understory plants in perennial plantations. Existence of inter-/intra-specific differences in shade tolerance in tropical cover crops/forage legumes have been reported [14, 16-20]. However the ability of crotalarias to grow at low PPFD is unknown. The $P_{\mathrm{N}}$ in Crotalaria brevidens increased rapidly with increasing irradiance to $1000 \mu \mathrm{mol} \mathrm{m} \mathrm{m}^{-2} \mathrm{~s}^{-1}$ and increased gradually with further increases in irradiance to $2000 \mu \mathrm{mol} \mathrm{m}^{-2} \mathrm{~s}^{-1}$ [21].

The carbon dioxide concentration $\left(\mathrm{C}_{\mathrm{a}}\right)$ in the atmosphere has risen from $280 \mathrm{~cm}^{3} \mathrm{~m}^{-3}$ in 1900 to present day levels of around $390 \mathrm{~cm}^{3} \mathrm{~m}^{-3}$ and is expected to approach $700 \mathrm{~cm}^{3} \mathrm{~m}^{-3}$ by the end of the $21^{\text {st }}$ century [10]. Litter decomposition in plantation crops contributes additional $\mathrm{C}_{\mathrm{a}}$ at ground level. Elevated $\mathrm{C}_{\mathrm{a}}$ also contributes to increased plant biomass and enhanced $P_{\mathrm{N}}$ [22-24]. Therefore, rising concentrations of atmospheric $\mathrm{C}_{\mathrm{a}}$ could increase $P_{\mathrm{N}}$ per unit leaf area of $\mathrm{C} 3$ plants. However, in many species, such an increase in $P_{\mathrm{N}}$ is often reduced after prolonged exposure to elevated $C_{a}[25$, 26]. Increases in $C_{a}$ increased the growth of many $C_{3}$ plants [27]; however, growth is usually not as large as would be predicted simply from the increase in photosynthesis [28-30]. Elevated $C_{a}$ increases plant biomass by increasing $P_{\mathrm{N}}$ and water use efficiency (WUE) and by decreasing transpiration rate (E) through reduced stomatal conductance $[24,30]$. Doubling atmospheric $\mathrm{C}_{\mathrm{a}}$ reduced stomatal 
conductance in C3 annual crop plants by 34\% [25]. Such phenomena have been documented in other plant species $[25,32]$. Vu [33] reported that peanut (Arachis hypogaea L.) leaves grown under elevated $\mathrm{C}_{\mathrm{a}}\left(720 \mu \mathrm{mol} \mathrm{mol}{ }^{-1}\right)$ had higher midday photosynthetic $\mathrm{CO}_{2}$ exchange rates (CER), lower transpiration and higher WUE, than leaves grown under at ambient $\mathrm{C}_{\mathrm{a}}\left(360 \mu \mathrm{mol} \mathrm{mol}^{-1}\right)$. In an evergreen forest, stomatal conductance is an important limiting factor for photosynthetic responses of understory plants to sunflecks [34]. Sunflecks account for $40 \%$ or more of the total daily photon flux density received by understory plants in evergreen forests, and high $\mathrm{C}_{\mathrm{a}}$ might allow understory plants to exploit sunflecks more efficiently $[35,36]$.

It has been projected that global surface temperature is likely to increase by $5.8^{\circ} \mathrm{C}$ by the end of this century due to increases in tracer gases, including $\mathrm{CO}_{2}[37,38]$. In legumes, radiation use efficiency is profoundly influenced by ambient temperature [39, 40]. Studies on elevated $\mathrm{C}_{\mathrm{a}}$ and temperature effects on $P_{\mathrm{N}}$ have been primarily reported for temperate, annual legume species [22-25, 33]. Recently, Baligar et al., [41] in a short term study reported that by increasing ambient temperature from $30{ }^{\circ} \mathrm{C}$ to $35{ }^{\circ} \mathrm{C}$ differential responses of $P_{\mathrm{N}}$ were observed in tropical perennial legumes. In this study, increasing temperature reduced $P_{\mathrm{N}}$ in these legumes. Information is lacking on the effects of increased atmospheric $\left[\mathrm{CO}_{2}\right]$, increased temperature, and reduced light on $P_{\mathrm{N}}$ of understory perennial legumes. Crotalarias are grown in a temperature range of 16 to $26^{\circ} \mathrm{C}$ [3] and are known to tolerate temperatures as low as $12^{\circ} \mathrm{C}$ and as high as $35^{\circ} \mathrm{C}$ [1]; however, the optimal temperature range for $P_{\mathrm{N}}$ in many of the tropical cover crops is not well documented. Canopy temperature of understory plants is less than plants under no shade [42]. High temperature often reduces growth and biomass by decreasing photosynthesis and increasing $\mathrm{E}$ [43]. In peanut, leaf water potential, hydraulic conductivity $(\mathrm{gh})$, transpiration rate $(\mathrm{E})$ and stomatal conductance $\left(\mathrm{g}_{\mathrm{s}}\right)$ increased with increasing soil temperature [40]. Imbamba and Tieszen [21] reported that $P_{\mathrm{N}}$ in Crotalaria brevidens decreased with increases in leaf temperature from 10 to $50^{\circ} \mathrm{C}$. However the rate of transpiration increased with increasing leaf temperature. Leaf diffusive resistance decreased with increasing irradiance but increased with increasing leaf temperature [21].

The objectives of the current study were to evaluate the independent short-term effects of photosynthetic photon flux density (PPFD), external carbon dioxide concentration $\left(\mathrm{C}_{\mathrm{a}}\right)$ and temperature $(\mathrm{T})$ on net photosynthesis $\left(P_{\mathrm{N}}\right)$ and photosynthetic components $\left(\mathrm{g}_{\mathrm{s}}, \mathrm{E}, \mathrm{C}_{\mathrm{i}}\right)$ in four crotalaria species: Crotalaria breviflora, C. mucronata, C. ochroleuca, and C. spectabilis.

\section{MATERIALS AND METHODS}

\section{Crotalarias Used and Growth Conditions}

Cover crops selected for study were: Showy Croalaria (Crotalaria spectabilis Roth), Short Flowered Crotalaria (Crotalaria breviflora DC.), Smooth Crotalaria (Crotalaria pallida Aiton/ mucronata Desv.), Rattlebox (Crotalaria ochroleuca G. Don). Crotalaria belongs to the Fabaceae (Leguminosae/Papilionace) family and genus Crotalaria [44]. Showy Crotalaria is an annual/perennial non climbing herb/shrub with potential for soil erosion control and known improver of soil. Short Flowered Crotalaria is a perennial non climbing herb/shrub and known improver of soil quality parameters. Smooth Crotolaria is annual/perennial non climbing herb and is a known improver of soil quality parameters. Rattlebox Crotalaria is an annual/perennial, erect/semi-erect non climbing herb/shrub [6, 45]. Seeds of various crotalarias were obtained from Pirai Seed Company, Av. Cassio Paschoal Pado.Vam; No 333, Piracicaba-SP Brazil.

Plants were grown in plastic pots containing $2 \mathrm{~kg}$ of 2:2:1 mixture of Sand: Perlite: Peat moss medium ( $\mathrm{pH}$ 5.0) and supplemented with all the essential nutrients $(\mathrm{mg} / \mathrm{kg})$ of $600 \mathrm{~N}, 600 \mathrm{P}, 240 \mathrm{~K}, 1012 \mathrm{C}, 309 \mathrm{Mg}, 500 \mathrm{~S}, 119 \mathrm{Fe}, 0.7 \mathrm{~B}$, 17.5 Mn, $7 \mathrm{Cu}, 7 \mathrm{Zn}$ and $0.35 \mathrm{Mo}$. Nutrients were applied as Osmocote (18-6-12; Scotts, Marysville, Ohio), triple super phosphate, urea, calcium sulphate, dolomitic lime, and Scott's micromix. During growth soil moisture was maintained near field capacity $(33 \mathrm{kPa})$. Plants were grown for 36 days in a greenhouse under $400 \pm 50 \mu \mathrm{mol} \mathrm{m}^{-2} \mathrm{~s}^{-1}$ of PPFD for $12 \mathrm{~h}, 370 \pm 30 \mathrm{~cm}^{3} \mathrm{~m}^{-3}$ of carbon dioxide and day and night temperatures of $32 \pm 5^{\circ} \mathrm{C}$ and $15 \pm 5^{\circ} \mathrm{C}$, respectively.

\section{Determination of Net Photosynthesis and Its Components $\left(C_{i}, g_{s}, E\right)$}

On the $34^{\text {th }}$ day of growth, plants were moved to a controlled environment chamber with $400 \mu \mathrm{mol} \mathrm{m}^{-2} \mathrm{~s}^{-1}$ of irradiance (PPFD) for $12 \mathrm{~h}, 370 \pm 30 \mathrm{~cm}^{3} \mathrm{~m}^{-3}$ of $\mathrm{C}_{\mathrm{a}}$ and a constant temperature of $25^{\circ} \mathrm{C}$. After two days in the growth chamber, 3 plants per species were subjected to photosynthetic determinations. Photosynthesis was measured on the third leaf from the top of each plant using a CIRAS-2 portable gas exchange system (PP Systems, Haverhill, MA, USA) with a $2.5 \mathrm{~cm}^{2}$ leaf chamber. The air flow rate was $200 \mathrm{~cm}^{3} \mathrm{~s}^{-1}$. PPFD was supplied by the CIRAS LED light source. Temperature was controlled by peltier elements on the leaf chamber unit. $\left[\mathrm{CO}_{2}\right]$ was controlled by the CIRAS-2 instrument.

\section{Experiment I: Effect of Light [PPFD] Intensity}

The third leaf was placed in the cuvette of the CIRAS-2 system and adjusted to conditions of PPFD of $1500 \mu \mathrm{mol}$ $\mathrm{m}^{-2} \mathrm{~s}^{-1}$, T of $30^{\circ} \mathrm{C}, \mathrm{C}_{\mathrm{a}}$ of $400 \mathrm{~cm}^{3} \mathrm{~m}^{-3}$ and VPD (vapor pressure deficit) of $2.0-2.5 \mathrm{kPa}$. After the leaf gas exchange became constant, the PPFD was adjusted in gradual steps to $1000,500,300,100,50 \mu \mathrm{mol} \mathrm{m}^{-2} \mathrm{~s}^{-1}$. The leaf was allowed to equilibrate at the chosen PPFD for $10 \mathrm{~min}$ and $P_{\mathrm{N}}$ and its components $\mathrm{C}_{\mathrm{i}}, \mathrm{g}_{\mathrm{s}}$, E were determined.

\section{Experiment II: Effect of Carbon Dioxide Concentration $\left(\boldsymbol{C}_{a}\right)$}

The third leaf was placed in the cuvette with PPFD of $1500 \mu \mathrm{mol} \mathrm{m} \mathrm{m}^{-2}$, VPD of $2.0-2.5 \mathrm{kPa}$, and temperature of $30^{\circ} \mathrm{C}$. The carbon dioxide concentration was initially adjusted to $400 \mathrm{~cm}^{3} \mathrm{~m}^{-3}$. After the leaf gas exchange became constant, the $C_{a}$ was adjusted in gradual steps to 100,250 , 700 and $1000 \mathrm{~cm}^{3} \mathrm{~m}^{-3}$. The leaf was allowed to equilibrate at the chosen $\mathrm{C}_{\mathrm{a}}$ for $10 \mathrm{~min}$ and $P_{\mathrm{N}}$ and its components $\mathrm{C}_{\mathrm{i}}, \mathrm{g}_{\mathrm{s}}, \mathrm{E}$ were determined.

\section{Experiment III: Effect of Temperature (T)}

The third leaf was placed in the cuvette and leaf temperature was adjusted to $25^{\circ} \mathrm{C}$ with PPFD of $1500 \mu \mathrm{mol}$ $\mathrm{m}^{-2} \mathrm{~s}^{-1}, \mathrm{C}_{\mathrm{a}}$ at $400 \mathrm{~cm}^{3} \mathrm{~m}^{-3}$ and the VPD at 2.0-2.5 $\mathrm{kPa}$. After 
the leaf gas exchange became constant, the temperature was adjusted in gradual steps to 28,30 , and $35^{\circ} \mathrm{C}$. The leaf was allowed to equilibrate at the chosen temperature for $10 \mathrm{~min}$ and $P_{\mathrm{N}}$ and its components $\mathrm{C}_{\mathrm{i}}, \mathrm{g}_{\mathrm{s}}, \mathrm{E}$ were determined. In this experiment, VPD increased with temperature, with mean values of $1.71,2.15,2.57,3.66 \mathrm{kPa}$ at $25,28,30$ and $35^{\circ} \mathrm{C}$, respectively.

\section{Statistics}

Standard deviation of data points of various measurements of each leaf were determined by SigmaPlot Ver. 10 and values were plotted on the graphs.

\section{RESULTS AND DISCUSSION}

\section{PPFD Effects}

In all species, increasing PPFD from 50 to $1500 \mu \mathrm{mol}$ $\mathrm{m}^{-2} \mathrm{~s}^{-1}$ increased $P_{\mathrm{N}}$ (Fig. 1A). Overall, there was a 21 fold increase in $P_{\mathrm{N}}$ from 50 to $1500 \mu \mathrm{mol} \mathrm{m} \mathrm{s}^{-2}$ of PPFD, and $P_{\mathrm{N}}$ continued its upward trend at $1500 \mu \mathrm{mol} \mathrm{m}^{-2} \mathrm{~s}^{-1}$ suggesting that it had not reached irradiance saturation. $P_{\mathrm{N}}$ values among four crotalaria species converged as the PPFD decreased but were divergent at $1500 \mu \mathrm{mol} \mathrm{m}^{-2} \mathrm{~s}^{-1}$ of PPFD. Baligar et al., [41] reported a similar trend in effects of varying PPFD on $P_{\mathrm{N}_{2}}$ of five tropical perennial legumes. PPFD of $500 \mu \mathrm{mol} \mathrm{m} \mathrm{m}^{-2} \mathrm{~s}^{-1}$ gave $66 \%$ of the maximum $P_{\mathrm{N}}$ at $1500 \mu \mathrm{mol} \mathrm{m} \mathrm{m}^{-2} \mathrm{~s}^{-1}$. C. breviflora and C. ochroleuca were always higher than C. mucronata and $C$. spectabilis. Imbamba and Tieszen [21] reported that $P_{\mathrm{N}}$ in $C$. brevidens increased with increases in PPFD up to $1000 \mu \mathrm{mol} \mathrm{m}{ }^{-2} \mathrm{~s}^{-1}$ and increased gradually with further increases in PPFD to $2000 \mu \mathrm{mol} \mathrm{m} \mathrm{m}^{-2}$. Crotalaria species used in our study were very sensitive to low irradiance confirming the observations of Ludlow and Wilson [46] and Wilson and Ludlow [47] that $P_{\mathrm{N}}$ of understory legumes is influenced by the amount of radiation reaching the crop canopy. Soils receive full sunlight early during establishment of tree crops either in an agroforestry system or non agroforestry system, but the amount of light that reaches the soil is drastically reduced as the trees grow. Miyaji et al., [8] reported that in Bahia, Brazil, above the canopy of shaded and non shaded cacao the light intensity ranged from 600 to $2000 \mu \mathrm{mol} \mathrm{m}^{-2} \mathrm{~s}^{-1}$ and at ground level the light intensity was 80 to $200 \mu \mathrm{mol} \mathrm{m} \mathrm{m}^{-2}$. Our results indicate that all four crotalarias species would photosynthesize adequately in newly established plantations. However, growth would be reduced dramatically as the trees matured and incident light levels fell below $500 \mu \mathrm{mol} \mathrm{m}^{-2} \mathrm{~s}^{-1}$. This confirms the notion that legume cover crops do well in early stages of tree fruit crops establishment, such as cacao, due to availability of high light intensity. However, as the trees mature, the growth, persistence and effectiveness of cover crops are reduced owing to low light intensity.

$P_{\mathrm{N}}$ recorded at higher PPFD is comparable to those reported for temperate and tropical legumes [30, 47]. At all levels of PPFD, C. breviflora and C. ochroleuca produced higher $P_{\mathrm{N}}$ than the other two crotalarias, indicating that these two grow well under no shade or moderate shade. Inter-/intra specific differences in shade tolerance of tropical legumes has been widely reported $[14,16,17,41,48,49]$. Information is lacking on the response of crotalarias to shade in plantation crop systems. Crotalarias that tolerate lower PPFD have a better chance of growing as understory plants and protecting soil longer in plantation crop systems. To make crotalarias more productive and efficient as cover crops in plantation agriculture, it is essential to manage canopies of associated shade trees to reduce excess shading.

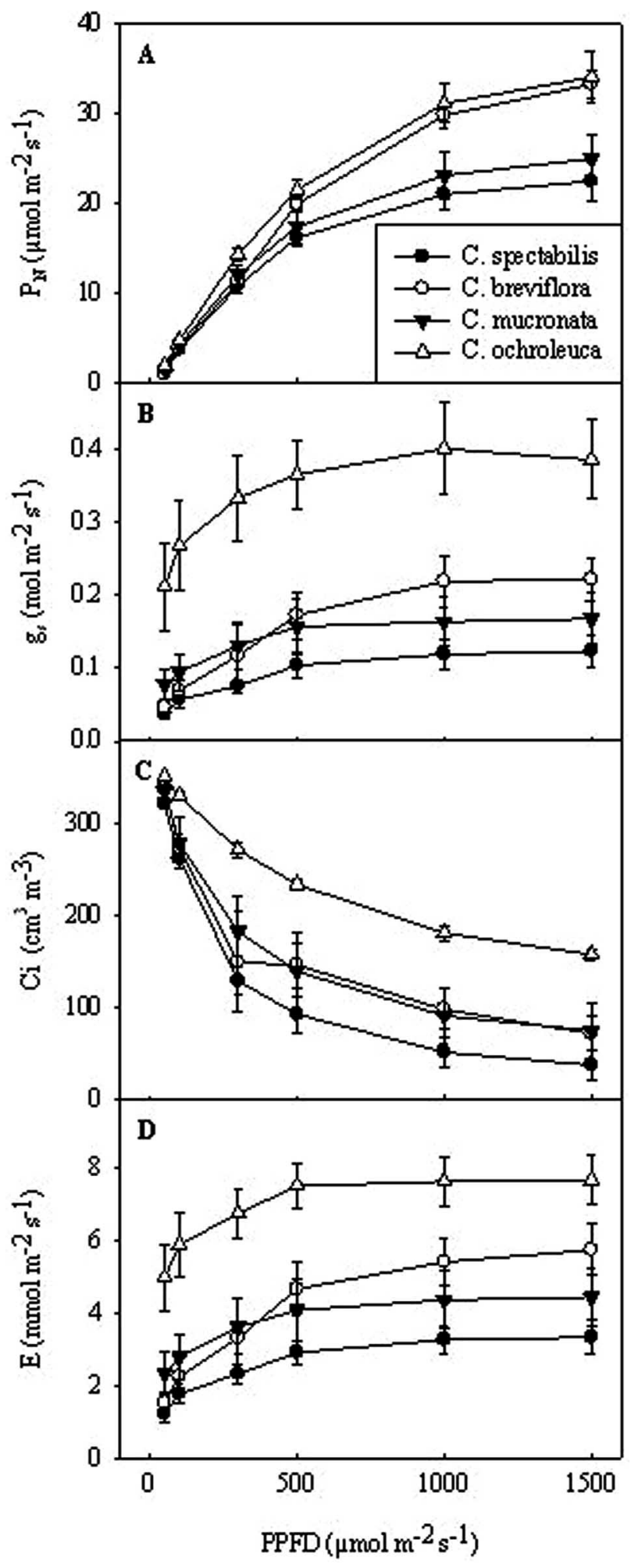

Fig. (1). Effect of PPFD levels on (A) net photosynthetic rate, $P_{\mathrm{N}} ;(\mathbf{B})$ stomatal conductance, $\mathrm{g}_{\mathrm{s}} ; \mathbf{( C )}$ internal $\mathrm{CO}_{2}$ concentration, $\mathrm{C}_{\mathrm{i}}$; and $(\mathbf{D})$ transpiration rate, E, of four Crotalaria genotypes at $\mathrm{T}$ of $30^{\circ} \mathrm{C}$ and $\mathrm{C}_{\mathrm{a}}$ of $400 \mathrm{~cm}^{3} \mathrm{~m}^{-3}$. Each symbol represents the average of three reps. 
In understory plants, stomatal conductance $\left(g_{s}\right)$ sometimes plays a vital role in regulating $P_{\mathrm{N}}$. Increasing $g_{s}$ with increasing PPFD is necessary to support higher $P_{\mathrm{N}}$ (Fig. 1B). Crotalarias having high $P_{\mathrm{N}}$ showed significantly higher $g_{s}$ at all the PPFD rates evaluated. In all crotalarias, $g_{s}$ increased up to $500 \mu \mathrm{mol} \mathrm{m}^{-2} \mathrm{~s}^{-1}$ of PPFD then remained fairly constant with further increases in PPFD. High $g_{s}$ due to wide stomatal openings increases water loss through transpiration, which can be detrimental by inducing water stress in low rainfall situations. C. ochroleuca at all the PPFD had 3 to 4 times higher $g_{s}$ than other crotalarias indicating that this crotalaria is potentially very susceptible to drought stress.

Internal $\mathrm{CO}_{2}(\mathrm{Ci})$ decreased as the PPFD increased for all crotalaria species (Fig. 1C). This is expected because higher irradiance levels increase $P_{\mathrm{N}}$, using more of the available internal $\mathrm{CO}_{2}$ thereby giving an inverse relationship between the two. Transpiration (E) followed a pattern similar to that of $g_{s}$ (Fig. 1D).

\section{$\mathrm{C}_{\mathrm{a}}$ Effects}

Increasing the external $\mathrm{CO}_{2}$ concentration from 100 to $1000 \mathrm{~cm}^{3} \mathrm{~m}^{-3}$ increased $P_{\mathrm{N}}$ of crotalaria species by 5 fold. Increasing $C_{\mathrm{a}}$ from 400 to $700 \mathrm{~cm}^{3} \mathrm{~m}^{-3}$ increased $P_{\mathrm{N}}$ by 1.4 times (Fig. 2A). In $\mathrm{C} 3$ plants, Kimball [50] and Drake and Leadley [26] reported that high atmospheric $\left[\mathrm{CO}_{2}\right]$ increased $P_{\mathrm{N}}$ rates and decreased $g_{s}$ and E. In our study $P_{\mathrm{N}}$ response in all four crotalarias suggests that increasing atmospheric $\left[\mathrm{CO}_{2}\right]$ will have beneficial effects on $P_{\mathrm{N}}$ thereby improving their growth and persistence at an adequate PPFD. If anticipated global $C_{a}$ of $700 \mathrm{~cm}^{3} \mathrm{~m}^{-3}$ by the end of $21 \mathrm{st}$ century are realized [10], these crotalaria species would respond well to the new conditions in tropical plantations. The findings in this study of a positive response of $P_{\mathrm{N}}$ with increasing $\mathrm{C}_{\mathrm{a}}$ confirm the findings of Bhagsari and Brown [51] and Baligar et al., [41]. Higher $\mathrm{C}_{\mathrm{a}}$ might allow the understory plants to use sunflecks more efficiently. Sunflecks accounted for $40 \%$ or more of daily photon flux density received by understory plants in evergreen forests $[35,36]$.

Increases in $\mathrm{C}_{\mathrm{a}}$ from 100 to $1000 \mathrm{~cm}^{3} \mathrm{~m}^{-3}$ decreased $g_{s}$ (Fig. 2B) and E (Fig. 2D), depending on species. For C. spectabilis and C. mucronata, $g_{s}$ decreased 1.5 and 2.6 times, respectively, while C. breviflora and C. ochroleuca remained relatively constant. E followed patterns similar to those of $g_{s}$. It has been widely reported that in most plants, elevated $C_{a}$ decreased evapotranspiration through reduction of $g_{s}[24,26,31,50]$. However, Baligar et al., [41] reported the reduction of $g_{s}$ and $\mathrm{E}$ in only one tropical legume (Leucaena leucocephala) with increasing $\mathrm{C}_{\mathrm{a}}$.

Internal $\mathrm{CO}_{2}(\mathrm{Ci})$ increased as external $\left[\mathrm{CO}_{2}\right]$ increased from 100 to $1000 \mathrm{~cm}^{3} \mathrm{~m}^{-3}$ (Fig. 2C). The exception was $C$. mucronata in which $\mathrm{Ci}$ increased with increased $\mathrm{C}_{\mathrm{a}}$ up to 700 $\mathrm{cm}^{3} \mathrm{~m}^{-3}$ and leveled off with further increases in $\mathrm{C}_{\mathrm{a}}$.

\section{T Effects}

Globally, it has been projected that, by the end of this century, surface temperature will increase by $5.8^{\circ} \mathrm{C}[37,38]$, and such an increase in temperature might have considerable influence on the $P_{\mathrm{N}}$ and its components in understory plants.

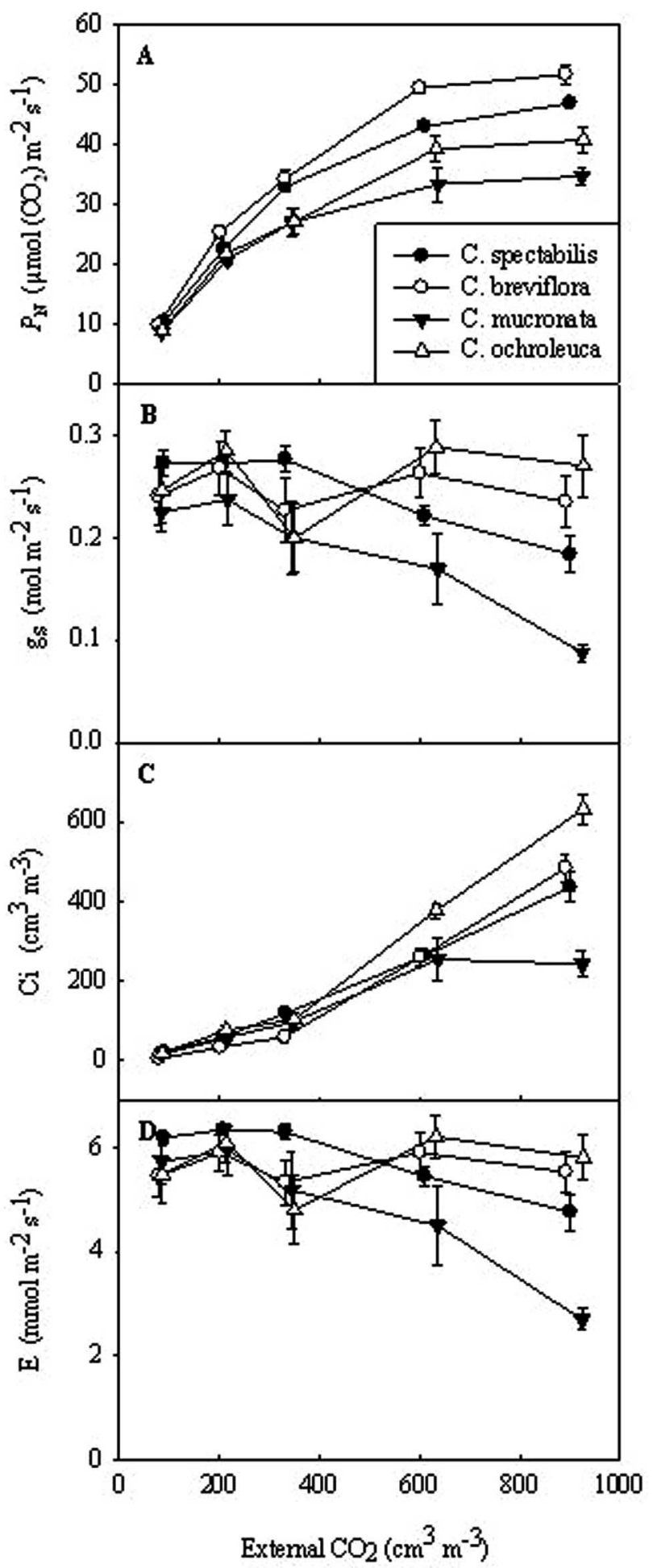

Fig. (2). Effect of external $C_{a}$ levels on (A) net photosynthetic rate, $P_{\mathrm{N}} ;(\mathbf{B})$ stomatal conductance, $\mathrm{g}_{\mathrm{s}} ;(\mathbf{C})$ internal $\mathrm{CO}_{2}$ concentration, $\mathrm{C}_{\mathrm{i}}$; and $(\mathbf{D})$ transpiration rate, $\mathrm{E}$ of four Crotalaria genotypes at $\mathrm{T}$ of $30{ }^{\circ} \mathrm{C}$ and PPFD of $1500 \mu \mathrm{mol} \mathrm{m} \mathrm{msec}^{-1}$. Each symbol represents the average of three reps.

Shade from the overstory trees reduces warming of the soil and air above the canopy of understory plants [42, 47]. Temperature optima for many tropical legumes have been reported in the range of 15 to $35^{\circ} \mathrm{C}$ [52-54]. In our study, 


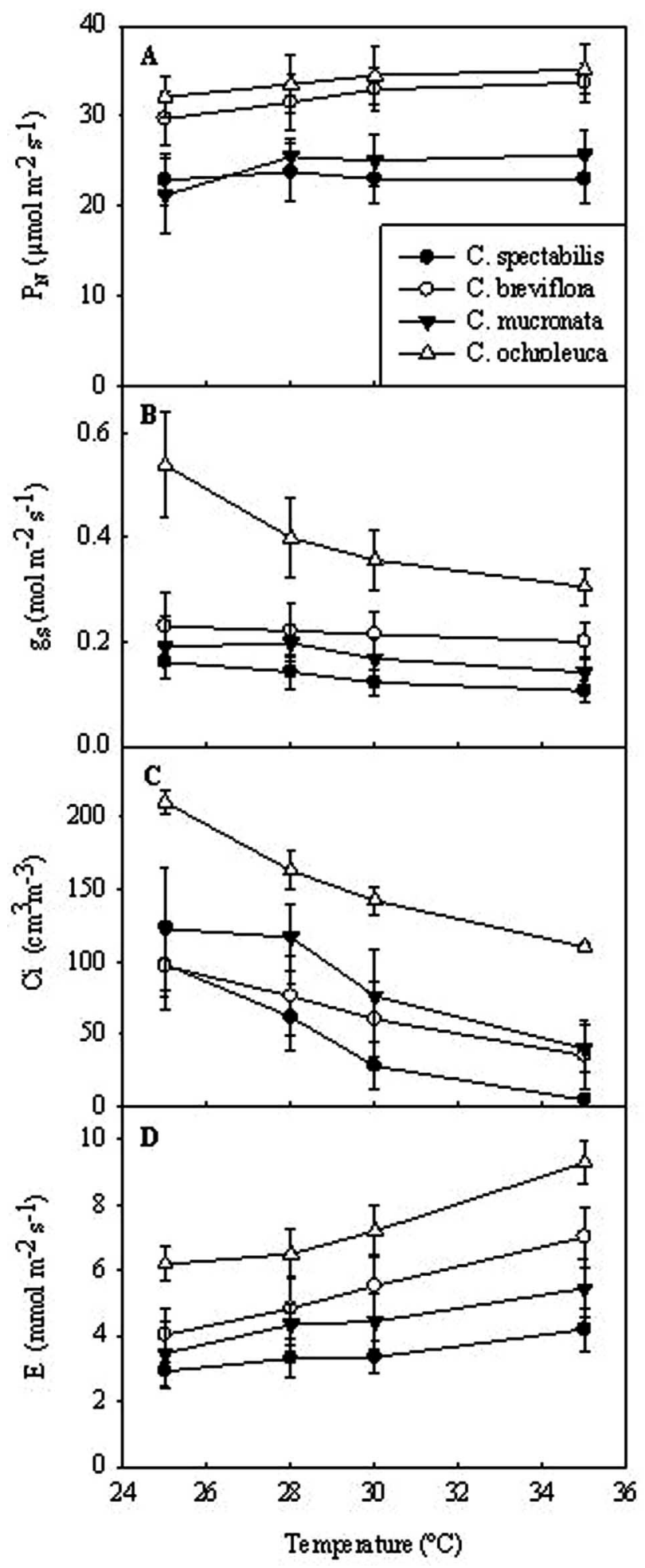

Fig. (3). Effect of temperature on (A) net photosynthetic rate, $P_{\mathrm{N}}$; (B) stomatal conductance, $\mathrm{g}_{\mathrm{s}}$; (C) internal $\mathrm{CO}_{2}$ concentration, $\mathrm{C}_{\mathrm{i}}$; and (D) transpiration rate, $\mathrm{E}$ of four Crotalaria genotypes at PPFD of $1500 \mu \mathrm{mol} \mathrm{m} \mathrm{sec}^{-1}$ and $\mathrm{C}_{\mathrm{a}}$ of $400 \mathrm{~cm}^{3} \mathrm{~m}^{-3}$. Each symbol represents the average of three reps.

increasing temperatures in the range of 25 to $35^{\circ} \mathrm{C}$ had little effect on $P_{\mathrm{N}}$ of the four crotalaria species (Fig. 3A). These findings differ with those of Imbamba and Tieszen [21] who reported that $P_{\mathrm{N}}$ in $C$. brevidens decreased with increasing leaf temperature from 10 to $50{ }^{\circ} \mathrm{C}$. The observed $P_{\mathrm{N}}$ values in the current study are different from those of many temperate, annual legume species as well, where $P_{\mathrm{N}}$ began to decrease with increasing temperature [22, 33, 39, 40]. Baligar et al., [41] recently reported that increasing temperature from 30 to $35^{\circ} \mathrm{C}$ reduced $P_{\mathrm{N}}$ in several tropical cover crop legumes. Differences in $P_{\mathrm{N}}$ values obtained in the current study are not in agreement with those other literature values and are probably due to differences in leaf residence time used to measure $P_{\mathrm{N}}$ at various temperatures. Longer exposure of leaves to various temperatures might have given different values for $P_{\mathrm{N}}$.

With the exception of $C$ ochroleluca, stomatal conductance $\left(\mathrm{g}_{\mathrm{s}}\right)$ remained constant over the range of 25 to $35^{\circ} \mathrm{C}$ for C. breviflora, C. spectabilis and C. mucronata (Fig. 3B). The $\mathrm{g}_{\mathrm{s}}$ of $C$. ochroleuca decreased 1.8 times from 25 to $35^{\circ} \mathrm{C}$. In all four crotalaria species studied, $\mathrm{Ci}$ declined rapidly with increasing temperature and was inversely related to $P_{\mathrm{N}}\left(\right.$ Fig. 3C). Internal $\mathrm{CO}_{2}(\mathrm{Ci})$ decreased by an average of 2.8 times from 25 to $35{ }^{\circ} \mathrm{C}$. Transpiration (E) in all crotalaria species increased by an average of 1.5 times from 25 to $35^{\circ} \mathrm{C}$ (Fig. 3D), partly because of the increase in VPD with temperature. These findings support the earlier report of Imbama and Tieszen [21] with C. brevidens. In low rainfall areas or in drought conditions increasing ambient temperatures could induce water stress in crotalaria species. However increasing temperature had no effect on $g_{s}$ and this could reduce the loss of water from leaves.

\section{CONCLUSIONS}

This study has clearly demonstrated that increasing light intensity and carbon dioxide enhanced photosynthesis in all of the crotalaria species. Increasing temperature from 25 to $35^{\circ} \mathrm{C}$ had little effect on $\mathrm{P}_{\mathrm{N}}$ of crotalaria. Shade management of overstory trees is essential to maintain the persistence and productivity of crotalaria species in tree plantations.

\section{CONFLICT OF INTEREST}

Declared none.

\section{ACKNOWLEDGEMENTS}

We thank Pamela Brozowski for competent technical assistance and our great appreciation and thanks to Drs. C. D. Foy and A. Alva for their excellent peer review of this manuscript and excellent suggestions.

\section{REFERENCES}

[1] Fageria NK, Baligar VC, Jones CA. Growth and Mineral Nutrition of Field Crops, $3^{\text {rd }}$ ed. CRC Press: Boca Raton, FL 2011; p. 619.

[2] Fageria NK, Baligar VC, Bailey BA. Role of cover crops in improving soil and row crop productivity. Commun Soil Sci Plant Anal 2005; 36: 2733-57.

[3] Baligar VC, Fageria NK. Agronomy and physiology of tropical cover crops. J Plant Nutr 2007; 30: 1287-339.

[4] Fageria NK. Green manuring in crop production. J Plant Nutr 2007; 30: 691-719.

[5] Wood GAR, Lass RA. Cocoa, $4^{\text {th }}$ ed. Blackwell Publishing: Oxford, UK 2001; p. 620.

[6] Hanum FI, van der Maesen LJG, Eds. Plant resources of South-east Asia, No. 11, Auxiliary plants. Backhuys Publishers, Leiden: The Netherlands 1997; p. 389.

[7] Knight AP, Walter RG. A guide to plant poisoning of animals in North America. Teton New Media: Jackson, WY 2001; p. 367. 
[8] Miyaji KI, Da Silva WS, Alvim P de T. Longevity of leaves of a tropical tree, Theobroma cacao, grown under shading, in relation to position within the canopy and time of emergence. New Phytol 1997; 135: 445-54.

[9] Willson KC. Coffee, Cocoa and Tea. CABI Publishing: New York 1999; p. 285.

[10] Bolin B. The Kyoto negotiation on climate change: a science perspective. Science 1998; 279: 330-1.

[11] Wong CC. Shade tolerance of tropical forages: A review. In: Shelton HM and Stur WW, Eds. Forages for Plantation Crops. ACIAR (Aust Center for Int Agr Res) Proceedings, Canberra, ACT, Australia, no 32, 1991; pp. 64-9.

[12] Grace J, Lloyd J, Miranda AC, Miranda H, Gash JHC. Fluxes of carbon dioxide and water vapour over a $\mathrm{C}_{4}$ pasture in south-western Amazonia (Brazil). Aust J Plant Physiol 1998; 25: 519-30.

[13] Liang N, Tang Y, Okuda T. Is elevation of carbon dioxide concentration beneficial to seedling photosynthesis in the understory of tropical rain forests? Tree Physiol 2001; 21: 1047-55.

[14] Eriksen FI, Whitney AS. Growth and N fixation of some tropical forage legumes as influenced by solar radiation regimes. Agron J 1982; 74: 703-9.

[15] Fujita K, Matsumoto K, Ofosu-Budu GK, Ogata S. Effects of shading on growth and dinitrogen fixation of kudzu and tropical pasture legumes. Soil Sci Plant Nutr 1993; 39: 43-54.

[16] Wong CC, Sharudin MAM, Rahim H. Shade tolerance potential of some tropical forages for integration in plantations: 2. Legumes. MARDI Res Bull 1985; 13: 249-69.

[17] Shelton HM, Humphreys LR, Batello C. Pastures in the plantations of Asia and the Pacific: Performance and prospect. Trop Grasslands 1987; 21: 159-68.

[18] Chong DT, Tajuddin I, Abd Samat MS. Productivity of cover crops and natural vegetation under rubber in Malaysia. In: Shelton HM, Stur WW, Eds. Forages for Plantation Crops. ACIAR (Aust Center for Int Agr Res) Proc, Canberra, ACT, Australia, no 32, 1991; pp. 36-40.

[19] Rika IK, Mendra IK, Oka GM, Nurjaya OMG. New forage species for coconut plantations in Bali. In: Shelton HM, Stur WW, Eds. Forages for Plantation Crops. ACIAR (Aust Center for Int Agric Res), Canberra, ACT, Australia, Proc no 32, 1991; pp. 41-4.

[20] Stur WW. Screening forage species for shade tolerance-a preliminary report. In: Shelton HM, Stur WW, Eds. Forages for Plantation Crops. ACIAR (Aust Center for Int Agr Res) Canberra, ACT, Australia, Proc no 32, 1991; pp. 58-63.

[21] Imbamba SK, Tieszen LL. Influence of light and temperature on photosynthesis and transpiration in some $\mathrm{C} 3$ and $\mathrm{C} 4$ vegetable plants from Kenya. Physiol Plant 1977; 39: 311-6.

[22] Hogan KP, Smith AP, Ziska LH. Potential effects of elevated $\mathrm{CO}_{2}$ and changes in temperature on tropical plants. Plant Cell Environ 1991; 14: 763-78.

[23] Amthor JS. Terrestrial higher-plant response to increasing atmospheric $\left[\mathrm{CO}_{2}\right]$ in relation to global carbon cycle. Global Change Biol 1995; 1: 243-74.

[24] Long SP, Ainsworth EA, Rogers A, Ort DR. Rising atmospheric carbon dioxide: plants FACE the future. Ann Rev Plant Biol 2004; 55: 591-628.

[25] Cure JD, Acock B. Crop responses to carbon dioxide doubling: a literature survey. Agric Forest Meteorol 1986; 38: 127-45.

[26] Drake BG, Leadley PW. Canopy photosynthesis of crops and native plant communities exposed to long-term elevated $\mathrm{CO}_{2}$. Plant Cell Environ 1991; 14: 853-60.

[27] Poorter H. Interspecific variation in the growth response of plants to an elevated ambient $\mathrm{CO}_{2}$ concentration. Vegetatio 1993; 104/105: 77-97.

[28] Lloyd J, Farquhar GD. The $\mathrm{CO}_{2}$ dependence of photosynthesis, plant growth responses to elevated atmospheric $\mathrm{CO}_{2}$ concentrations and their interaction with soil nutrient status. I. General principles and forest ecosystems. Funct Ecol 1996; 10: 4-32.

[29] Marriott DJ, Stirling CM, Farrar J. Constraints to growth of annual nettle (Urtica urens) in an elevated $\mathrm{CO}_{2}$ atmosphere: Decreased leaf area ratio and tissue $\mathrm{N}$ cannot be explained by ontogenetic drift or mineral N supply. Physiol Plant 2001; 111: 23-32.
[30] Bunce JA. Effects of doubled atmospheric carbon dioxide concentration on the response of assimilation and conductance to humidity. Plant Cell Environ 1993; 16: 189-97.

[31] Morison JIL. Stomatal response to increased $\mathrm{CO}_{2}$ concentration. J Exp Bot 1998; 49: 443-52.

[32] Zhu J, Talbott LD, Jin X, Zeiger E. The stomatal response to $\mathrm{CO}_{2}$ is linked to changes in guard cell zeaxanthin. Plant Cell Environ 1998; 21: 813-20.

[33] Vu JCV. Acclimation of peanut (Arachis hypogaea L.) leaf photosynthesis to elevated growth $\mathrm{CO}_{2}$ and temperature. Environ Exp Bot 2005; 53: 85-95.

[34] Kirschbaum MUF, Pearcy RW. Gas exchange analysis of the relative importance of stomatal and biochemical factors in photosynthetic induction in Alocasia macrorrhiza. Plant Physiol 1988; 86: 782-5.

[35] Pearcy RW. The light environment and growth of $\mathrm{C}_{3}$ and $\mathrm{C}_{4}$ tree species in the understory of Hawaiian forest. Oecologia 1983; 58: 19-22.

[36] Chazdon RL, Fetcher N. Photosynthetic light environments in a lowland tropical rain forest in Costa Rica. J Ecol 1984; 72: 553-64.

[37] Wilson CA, Mitchell JF. A doubled $\mathrm{CO}_{2}$ climate sensitivity experiment with global climate model including a simple ocean. J Geophys Res 1987; 92: 13315-343.

[38] Houghton JT, Ding Y, Griggs DJ, Eds. Climatic change 2001: The scientific basis. Third Assessment Report of Working Group I of the Intergovernmental Panel on Climatic Change (IPCC), Cambridge University Press: Cambridge, UK 2001; p. 873.

[39] Sinclair TR, Muchow RC. Radiation use efficiency. Adv Agron 1999; 65: 215-65.

[40] Awal MA, Ikeda T. Effect of elevated soil temperature on radiation-use efficiency in peanut stands. Agric Forest Meteorol 2003; 118: 63-74.

[41] Baligar VC, Bunce JA, Elson MK, Fageria NK. Irradiance, external carbon dioxide concentration and temperature influence photosynthesis in tropical cover crop legumes. Trop Grasslands 2010; 44: 24-32.

[42] Chen CP. Problems and prospects of integration of forage into permanent crops. In: Halim RA, Ed. Grasslands and Forage Production in South-East Asia. Proc First Meeting Regional Working Group on Grazing and Feed Resources of South-East Asia, Serdang Malayasia 1989; pp. 128-39.

[43] Jones HG. Plants and microclimate: A quantitative approach to environmental plant physiology, $2^{\text {nd }}$ ed. Cambridge University Press: Cambridge, UK 1992; p. 428.

[44] USDA-ARS. Germplasm Resources Information Network (GRIN) Available from: http://www.ars-grin.gov/cgi-bin/npgs/html/tax search.pl [Accessed 2006 Nov 8].

[45] Roskov YR, Bisby FA, Zarucchi JL, Schrire BD, White RJ, Eds. ILDIS Legume Web. Available from: http://www.ildis.org/ [Accessed 2006 Nov 6].

[46] Ludlow MM, Wilson GL. Photosynthesis of tropical pasture plants I. Illuminance, carbon dioxide concentration, leaf temperature and leaf-air vapour pressure differences. Aust J Biol Sci 1971; 24: 449-70.

[47] Wilson JR, Ludlow MM. The environment and potential growth of herbage under plantations. In: Shelton HM, Stur WW, Eds. Forages for Plantation Crops. ACIAR (Aust Center for Int Agr Res), Canberra, ACT, Australia 1991; Proc No 32: 10-24.

[48] Baligar VC, Fageria NK, Paiva AQ, Silveira A, Pomella AWV, Machado RCR. Light intensity effects on growth and micronutrient uptake by tropical legume cover crops. J Plant Nutr 2006; 29: 1959-74.

[49] Baligar VC, Fageria NK, Paiva A, et al. Light intensity effects on growth and nutrient-use efficiency of tropical legume cover crops. In: Jose S, Gordon AM, Eds. Toward Agroforestry Design: An Ecological Approach, Springer, Netherlands. Adv Agroforestry 2008; 4: 67-79.

[50] Kimball BA. Carbon dioxide and agricultural yield: an assemblage and analysis of 430 prior observations. Agron J 1983; 75: 779-88. 
[51] Bhagsari AS, Brown RH. Relationship of net photosynthesis to carbon dioxide concentration and leaf characteristics in selected peanut (Arachis) genotypes. Peanut Sci 1976; 3: 10-4.

[52] Cooper AJ. Root temperature and plant growth: A review. CABI Res Review No 4. CABI, Farnham Royal, UK 1973.
[53] Duke JA, Ed. Handbook of Legumes of World Economic Importance. Scientific Publishers: Jodhpur, India 2002; p. 345.

[54] Cook BG, Pengelly BC, Brown SD, et al. Tropical Forages: An interactive selection tool. Available from: http://www.tropicalforages. info/key/Forages/Media/Html/index.htm [Accessed Oct 20, 2006].

Received: September 22, 2011

Revised: January 27, 2012

Accepted: February 27, 2012

(C) Baligar et al.; Licensee Bentham Open.

This is an open access article licensed under the terms of the Creative Commons Attribution Non-Commercial License (http://creativecommons.org/licenses/by$\mathrm{nc} / 3.0 /$ ) which permits unrestricted, non-commercial use, distribution and reproduction in any medium, provided the work is properly cited. 